УДК 343.242

DOI https://doi.org/10.32849/2663-5313/2020.6.37

\title{
Тетяна Дмитришина,
}

канд. юрид. наук,

старший викладач кафедри права

Вінницького національного аграрного університету

\section{ПРОБЛЕМИ ВДОСКОНАЛЕННЯ ІНСТИТУТУ ПОКАРАННЯ НЕПОВНОЛІТНІХ НА СУЧАСНОМУ ЕТАПI}

Статтю присвячено актуальним проблемам удосконалення інституту покарання неповнолітніх на сучасному етапі формування ювенального кримінального права в Україні. Визначено основні напрями впровадження кримінальної юстииї та здійснено аналіз нормативно-правової бази ювенального кримінального права. Розглянуто інститут покарання неповнолітніх як важливий елемент сучасного ювенального кримінального права та окреслено основні проблеми його функиіонування.

Зазначено, що упродовж останніх років внесено зміни до законодавства та прийнято низку правових актів, спрямованих на реформування законодавства у сфері ювенальної юстииї. Так, прийнято прогресивні зміни до Кримінального прочесуального кодексу України, Закон «Про пробацію» тощо. Однак не внесено жодних змін до Кримінального кодексу України щодо кримінальної відповідальності та покарання неповнолітніх.

Акцентовано увагу на тому, що важливим кроком для нашої держави стало запровадження системи пробаиї неповнолітніх, яка сприяє захисту їхніх прав. Здійснено аналіз статистичних даних щодо діяльності системи пробаиї, який свідчить про те, шо ефективність виховного впливу системи пробачії на неповнолітніх злочинців залишається недостатньою. Доведено, що одним з основних чинників, який негативно впливає на систему функиіонування ювенальної юстииї, є недосконалість кримінального законодавства. Запропоновано внести необхідні зміни до кримінального закону, які б відповідали принципу гуманізачї призначення покарання неповнолітнім. Наголошено на тому, шо основною метою покарання неповнолітніх злочиниів є його виховний вплив.

Зроблено висновок, що для досягнення максимального результату у боротьбі за зниження злочинності серед неповнолітніх, мінімізаиї кількості повторних злочинів, дотримання прав дитини необхідне системне реформування національного законодавства та прийняття спеціального закону про кримінальну відповідальність неповнолітніх.

Ключові слова: інститут покарання неповнолітніх, ювенальне кримінальне право, ювенальна юстиція, покарання, пробація, неповнолітні, Кримінальний кодекс України.

Постановка проблеми. В Україні формується система ювенального кримінального права, одним sз найважливіших інститутів якого є інститут покарання неповнолітніх. Загальносвітова тенденція відмови від карального підходу, гуманізація кримінальної політики ставить перед нашою державою низку завдань, які необхідно вирішити найближчим часом.

Ювенальна юстиція в Україні впроваджується на засадах доброзичливого до дитини сектору правосуддя. Саме такою є ключова ціль Міжвідомчої координаційної ради з питань правосуддя щодо неповнолітніх, до якої входять представники усіх органів влади, міжнародних організацій та громадських об'єднань. Одним із завдань Міжвідомчої координаційної ради з питань правосуддя щодо неповнолітніх $є$ удосконалення нормативно-правової бази кримі- нального закону [9]. Отже, сьогодні на державному рівні визначено основні пріоритети кримінальної політики щодо неповнолітніх, проголошено впровадження ювенальної юстиції, основною метою якої є забезпечення прав і свобод дитини.

I хоча Україною здійснено певні кроки для гуманізації інституту покарання неповнолітніх, цього не досить для дієвого впровадження ювенальної юстиції. Перед українським законодавцем стоїть важливе питання реформування кримінального закону в частині призначення покарань неповнолітнім, що потребує наукового підгрунтя, сучасних теоретичних підходів до проблеми призначення покарання неповнолітнім. Отже, удосконалення інституту покарання неповнолітніх є надзвичайно актуальною для кримінальної доктрини темою. 
Аналіз основних досліджень. Проблемі призначення покарань неповнолітнім присвячено багато наукових досліджень таких учених, як Н. Березовська, А. Білоконь, В. Бурдін, С. Вечерова, О. Дащенко, А. Клевцов, Н. Ковтун, А. Коновалова, Н. Максимова, Є. Назимко, О. Северин, О. Семерак, Н. Терещук, О. Яцун та інші. Однак проблема функціонування інституту покарання неповнолітніх залишається досить актуальною, особливо у контексті впровадження ювенальної юстиції в Україні.

Мета статті - дослідити основні проблеми інституту покарання неповнолітніх на сучасному етапі та обгрунтувати необхідність внесення змін до кримінального закону стосовно призначення покарання неповнолітнім.

Виклад основного матеріалу. Інститут покарання неповнолітніх на сучасному етапі $€$ важливим складником ювенальної юстиції в Україні, яка знаходиться на етапі активного впровадження.

Основні напрями реформування ювенальної юстиції визначені Концепцією розвитку кримінальної юстиції щодо неповнолітніх в Україні [3] та Національною стратегією реформування системи юстиції щодо дітей на період до 2023 року, спрямованою на розв'язання основних системних проблем юстиції щодо дітей [7].

Нормативно-правову базу ювенального кримінального права становлять міжнародні нормативні акти (Конвенція ООН «Про права дитини», 1989 р.; Декларація прав дитини, 1959 р.; Мінімальні стандартні правила ООН, які стосуються відправлення правосуддя щодо неповнолітніх (Пекінські правила, 1985 р.) тощо), Конституція України, Кримінальний, Кримінально-виконавчий, Кримінальний процесуальний кодекси України, Закон «Про пробацію», постанови Кабінету Міністрів, вищих судових інстанцій та інші.

Слід зазначити, що упродовж останніх років прийнято низку нормативно-правових актів, спрямованих на удосконалення законодавства у сфері ювенальної юстиції. Це, зокрема, Стратегія розвитку державної молодіжної політики на період до 2020 року; Державна соціальна програма «Національний план дій щодо реалізації Конвенції ООН про права дитини» на період до 2021 року; план дій з реалізації Національної стратегії у сфері прав людини на період до 2020 року; Державна цільова соціальна програма «Молодь України» на 2016-2020 роки тощо.

Нормативно-правове забезпечення інституту покарання неповнолітніх становлять кримінально-правові норми, що містяться у Кримінальному кодексі України (ККУ). Ці норми визначають «мету, систему (види та розміри), особливості призначення покарань неповнолітнім».

Інститут покарання неповнолітніх у кримінальному праві України розглядається як система кримінально-правових норм, закріплених у положеннях Загальної та Особливої частин ККУ, яка визначає мету, систему (види та розміри), особливості призначення покарання дитині у віці від 16 років (в окремих, передбачених законом, випадках - від 14 років) [6, с. 111-122].

До системи кримінально-правових норм, що стосуються неповнолітніх, належать загальні норми (ст.ст. 22, 50, 53, 55, 56, 57, 60, 63, 65-73) і спеціальні норми, що містяться у розділі у Розділі XV Загальної частини ККУ «Особливості кримінальної відповідальності та покарання неповнолітніх» та регулюють особливості покарання неповнолітніх (ст.ст. 98-103) [4].

Слід звернути увагу на те, що після прийняття ККУ від 2001 року не було внесено суттєвих змін стосовно кримінальної відповідальності та призначення покарання неповнолітнім. Але ж потреба у таких змінах $€$ очевидною. Наприклад, до неповнолітніх, визнаних винними у вчиненні злочину, судом можуть бути застосовані такі основні види покарань, як штраф, громадські роботи, виправні роботи, арешт або позбавлення волі. Крім того, до неповнолітніх можуть бути застосовані додаткові покарання у вигляді штрафу та позбавлення права обіймати певні посади або займатися певною діяльністю (ст. 99-102). А на практиці, як правило, призначається один вид покарання - позбавлення волі.

У чому полягає особливість кримінальної відповідальності та покарання неповнолітніх? ККУ для неповнолітніх передбачена можливість звільнення неповнолітнього від кримінальної відповідальності із застосуванням до нього примусових заходів виховного характеру; скорочено види покарань та обмежено строки встановлених покарань; передбачено більш м'які вимоги (умови) для звільнення від кримінального покарання; зменшено строки, після спливу яких до неповнолітнього можливе застосування умовнодострокового звільнення, а також строки погашення і зняття судимості (ст. 103-107).

I хоча ККУ для неповнолітніх передбачені особливі, більш гуманні умови кримінальної відповідальності та покарання порівняно з дорослими злочинцями, проте часто ці особливості мають декларативний характер унаслідок відсутності механізму їх 
реалізації або неясності їх правової сутності, ролі в структурі кримінальної відповідальності і покарання неповнолітніх. Крім того, ряд розпоряджень сформульований без урахування правового положення неповнолітніх в інших галузях права.

Позитивним кроком у розвитку ювенальної юстиції стало запровадження нових підходів до здійснення судочинства у провадженнях щодо злочинів, вчинених неповнолітніми, що знайшли своє відображення у Кримінальному процесуальному кодексі України (КПК) [5].

Так, чинним КПК передбачена окрема глава «Кримінальне провадження щодо неповнолітніх», яка визначає загальні правила кримінального провадження щодо неповнолітніх і містить ряд прогресивних змін порівняно 3 попереднім кодексом. Так, у кримінальному провадженні щодо неповнолітніх проводиться комплексна психолого-психіатрична і психологічна експертиза неповнолітнього підозрюваного чи обвинуваченого; встановлюється обов'язок з'ясування умов життя та виховання неповнолітнього підозрюваного чи обвинуваченого (ст. 484-492). Також КПК передбачено участь законного представника, педагога, психолога або лікаря в допиті неповнолітнього підозрюваного чи обвинуваченого, встановлено порядок виклику неповнолітнього підозрюваного чи обвинуваченого, визначено процесуальні особливості допиту неповнолітнього підозрюваного чи обвинуваченого. КПК передбачено нормативне забезпечення механізму передання неповнолітнього підозрюваного чи обвинуваченого під нагляд батьків, опікунів чи піклувальників як окремого запобіжного заходу (ст. 497). Також врегульовано механізм застосування примусових заходів виховного характеру до неповнолітніх, які не досягли віку кримінальної відповідальності (ст. 498-502) [5].

Важливим законодавчим актом у сфері ювенальної юстиції є Закон України «Про пробацію» [1], яким впроваджено систему наглядових та соціально-виховних заходів, виконання певних видів кримінальних покарань, не пов'язаних з позбавленням волі, та встановлено обов'язок забезпечення суду інформацією, що характеризує обвинуваченого. Особливості пробації щодо неповнолітніх врегульовано ст. 12 цього Закону.

Можна сказати, що з прийняттям Закону «Про пробацію» було закладено фундаментальні основи системи ювенальної юстиції, що наблизило Україну до міжнародних та європейських стандартів стосовно захисту прав неповнолітніх.

У рамках реформування системи кримінальної юстиції щодо неповнолітніх в Укра- їні створено окрему організаційну структуру для забезпечення ювенальної пробації. Сьогодні в Україні діє 14 центрів ювенальної пробації (Дніпро, Кривий Ріг, Запоріжжя, Мелітополь, Маріуполь, Київ, Житомир, Львів, Рівне, Одеса, Миколаїв, Харків, Кропивницький, Полтава). У кожному центрі працюють керівник, інспектор, соціальний працівник, психолог. Основною ідеєю таких центрів для дітей $є$ надання послуг комплексної допомоги відповідно до криміногенних потреб неповнолітніх, які перебувають у конфлікті із законом [11].

Так, станом на 01.01.2020 р. на обліку підрозділів пробації перебувало 850 неповнолітніх. У 2019 році переважна кількість неповнолітніх засуджено за тяжкі злочини 499 (58,7 \%) осіб, за злочини середньої тяжкості - 328 (38,6 \%) осіб, невеликої тяжкості - 20 (2,4\%), особливо тяжкі - 3 (0,3\%) осіб.

За підсумками 2019 р. по обліку уповноважених органів з питань пробації пройшли 2248 неповнолітніх суб'єктів пробації, 59 з них скоїли нові злочини під час перебування на обліку уповноважених органів з питань пробації. Загальний рівень повторної злочинності під час перебування на обліку становить 2,6 \% (2016 - 110, або 2,6 \%, 2017 - 79, або 2,4 \%, 2018 - 64, або 2,6 \%) [8, c. 24-25].

Звичайно, запровадження системи пробації позитивно впливає на імідж нашої держави у світі, сприяє захисту прав неповнолітніх, забезпечує на практиці реалізацію основних принципів ювенальної юстиції. Проте про ефективність ювенальної пробації щодо запобігання злочинності, забезпечення виховної функції стосовно неповнолітніх злочинців робити висновки ще зарано.

На думку вітчизняних та закордонних експертів, система ювенальної пробації не $€$ досконалою та потребує якісних змін. Серед недоліків органів пробації $€$ недостатнє врахування гендерних особливостей неповнолітніх, спрямованість заходів на виправлення вже сформованої протиправної поведінки, а не на подолання факторів, що зумовили таку поведінку тощо [2, с. 107, 128].

Вважаємо, що одним із ключових чинників, який негативно впливає на систему становлення ювенальної юстиції (поряд із недоліками у системі профілактики злочинів неповнолітніх, недостатнім фінансуванням пробації, неузгодженістю діяльності різноманітних державних органів, що залучені до ювенальної пробації), є недосконалість кримінального законодавства. Тож необхідно внести ряд прогресивних змін до ювенального кримінального законодавства України 
загалом i, зокрема, в частині призначення покарання неповнолітнім, які б відповідали принципу гуманізації.

Сьогодні ККУ та деякі його положення, які стосуються призначення покарання неповнолітнім, не відповідають світовій практиці гуманізації покарання неповнолітніх. Для усунення цього потрібно внести зміни до низки статей ККУ з метою вдосконалення призначення покарання неповнолітнім. Так, необхідно внести зміни у ст. 97-103 ККУ, які стосуються визначення критеріїв мінімального карального впливу та пропорційності, та додати нові статті, які б регламентували процес призначення покарання.

Важаємо, що основною метою кримінального покарання неповнолітніх є процес виховання, тож необхідно, щоб мета виховання неповнолітніх правопорушників дістала своє законодавче закріплення в чинному ККУ.

Крім того, потребує законодавчого вирішення необхідність перегляду санкцій статей Особливої частини ККУ на їх відповідність вимогам щодо покарань, які можуть бути застосовані до неповнолітніх, або закріплення в кримінальному законодавстві положення про право суду переходити до більш м'якого покарання за системою покарань, передбаченою ст. 51 ККУ, у випадках, коли жодне із запропонованих у санкції статті Особливої частини покарань не може бути застосоване до конкретного неповнолітнього.

Ми цілком погоджуємося з думкою, що «наявна в Україні системна роз'єднаність державних інститутів, що займаються проблемами неповнолітніх, не дає змоги досягти позитивних результатів у зниженні рівня злочинності серед неповнолітніх та у сфері захисту дитини від злочинного середовища. Подолання такого стану вбачається в об'єднанні зусиль різних державних органів і структур, а також громадських організацій в єдиному векторі цілісної системи ювенальної юстиції. Шлях до такої юстиції, що включає ювенальні суди, спеціалізовану адвокатуру, самостійну систему слідчих апаратів, виховні заклади, соціальні органи й заклади освіти, які займаються вихованням важких підлітків, вимагає вже на сучасному етапі вирішення багатьох практичних та теоретичних питань, одним із яких є розроблення окремого Закону про кримінальну відповідальність неповнолітніх» [6, с. 66].

\section{Висновки}

Отже, інститут покарання неповнолітніх $€$ важливим елементом ювенального кримінального права в Україні та потребує удосконалення. Одним з основних чинників, який негативно впливає на систему функціону- вання ювенальної юстиції, є недосконалість кримінального законодавства в частині призначення покарання неповнолітнім. Тож необхідно внести зміни до кримінального закону, які б відповідали принципу гуманізації призначення покарання неповнолітнім та сприяли посиленню виховного впливу покарання на неповнолітніх злочинців. Крім того, для досягнення максимального результату у боротьбі за зниження злочинності серед неповнолітніх, мінімізації кількості повторних злочинів, дотримання прав дитини необхідне системне реформування національного законодавства та прийняття спеціального закону про кримінальну відповідальність неповнолітніх.

\section{Список використаних джерел:}

1. Про пробацію : Закон України від 05.02.2015 № 160-VIII. URL: https://zakon. rada.gov.ua/laws/card/160-19 (дата звернення: 25.05.2020).

2. Інститут пробації в Україні: сучасний стан і перспективи розвитку : матеріали міжнародного круглого столу (16 квітня 2019 року). Київ: Національна академія прокуратури України, 2019. 196 с URL: http://napu.com.ua/materialy/16.04.19 RT institut probacii.pdf (дата звернення: 04.06.2020)

3. Концепція розвитку кримінальної юстиції щодо неповнолітніх в Україні від 24.05.2011 № 597/211. URL: https://zakon.rada.gov. ua/laws/show/597/2011 (дата звернення: 25.05.2020).

4. Кримінальний кодекс України від 05.04.2001 № 2341-III. URL: https://zakon.rada gov.ua/laws/show/2341-14 (дата звернення: 25.05.2020)

5. Кримінальний процесуальний кодекс України від 13.04.2012 № 4651-VI. URL: https:/ zakon.rada.gov.ua/laws/show/4651-17 (дата звернення: 20.05.2020).

6. Назимко $€$. С. Інститут покарання неповнолітніх у кримінальному праві України : монографія. Київ : ВД «Дакор», 2018. 336 с.

7. Національна стратегія реформування системиюстиціїщододітейнаперіоддо 2023року:схвалена розпорядженням Кабінету Міністрів України від 18.12.2018 № 1027. URL: https://zakon. rada.gov.ua/laws/show/1027-2018-\%D1\%80 (дата звернення: 25.05.2020).

8. Огляд результатів діяльності Державної установи «Центр пробації за 2019 рік. URL https://drive.google.com/file/d/1VwGP0GdKcn 8T8vjb6llpqysn7hqf1YHu/view (дата звернення: 05.05.2020).

9. Положення про Міжвідомчу координаційну раду з питань правосуддя щодо неповнолітніх : затверджене Постановою Кабінету Міністрів України від 24.05.2017 № 357. URL: https://zakon. rada.gov.ua/laws/show/357-2017-\%D0\%BF (дата звернення: 17.05.2020)

10. Шехавцов Р.М., Хавронюк M.I. Звіт щодо кримінальної статистики в Україні. Київ, 2019. URL: https://rpr.org.ua/wp-content/ 
uploads/2019/09/1568808134cplr.-report-oncriminal-statistics-in-ukraine.pdf (дата звернення: 17.05.2020).
11. Центри ювенальної пробації. URL: https://www.probation.gov.ua/?page id=146 (дата звернення: 05.05.2020).

Tetiana Dmytryshyna. Problems of improving the institute of juvenile punishment at the present stage

The article is devoted to topical issues of improving the institution of juvenile punishment at the present stage of formation of juvenile criminal law in Ukraine. The main directions of introduction of criminal justice are defined and the analysis of normative-legal base of juvenile criminal law is carried out.

The article considers the institute of juvenile punishment as an important element of modern juvenile criminal law and outlines the main problems of its functioning.

It is noted that in recent years, changes have been made to the legislation and a number of regulations aimed at reforming the legislation in the field of juvenile justice have been adopted. Thus, progressive amendments to the Criminal Procedure Code of Ukraine, the Law "On Probation", etc. were adopted. Thus, no amendments have been made to the Criminal Code of Ukraine regarding the sentencing of minors.

Emphasis was placed on the fact that an important step for our state was the introduction of a system of probation for minors, which helps to protect the rights of minors. An analysis of statistics on the activities of the probation system, which shows that the effectiveness of the educational impact of the probation system on juvenile offenders remains insufficient. It is proved that one of the main factors that negatively affects the system of juvenile justice is the imperfection of criminal law. It is proposed to make the necessary changes to the criminal law, which would correspond to the principle of humanization of sentencing of minors. It is emphasized that the main purpose of punishing juvenile offenders is the educational impact.

It is concluded that in order to achieve the maximum result in the fight to reduce juvenile delinquency, minimize the number of recidivism, respect for children's rights, it is necessary to systematically reform national legislation and adopt a special law on criminal liability of minors.

Key words: institute of juvenile punishment, juvenile criminal law, juvenile justice, punishment, probation, juveniles, Criminal Code. 